\title{
The Relationship Between Marketing Mix and Customer Loyalty among Malaysian Smartphone Users
}

Nur Najjah Abd Rahim, Mohd Zamri Abu Bakar, Ariff Azly Muhamed, Mazuin Mat Halif, Mohd Faizul Hassan

To Link this Article: http://dx.doi.org/10.6007/IJARBSS/v12-i1/12196 DOI:10.6007/IJARBSS/v12-i1/12196

Received: 14 November 2021, Revised: 17 December 2021, Accepted: 09 January 2022

Published Online: 23 January 2022

In-Text Citation: (Rahim et al., 2022)

To Cite this Article: Rahim, N. N. A., Bakar, M. Z. A., Muhamed, A. A., Halif, M. M., \& Hassan, M. F. (2022). The Relationship Between Marketing Mix and Customer Loyalty among Malaysian Smartphone Users. International Journal of Academic Research in Business and Social Sciences, 12(1), 2270-2276.

\section{Copyright: @ 2022 The Author(s)}

Published by Human Resource Management Academic Research Society (www.hrmars.com)

This article is published under the Creative Commons Attribution (CC BY 4.0) license. Anyone may reproduce, distribute, translate and create derivative works of this article (for both commercial and non0-commercial purposes), subject to full attribution to the original publication and authors. The full terms of this license may be seen at: http://creativecommons.org/licences/by/4.0/legalcode

Vol. 12, No. 1, 2022, Pg. 2270- 2276

Full Terms \& Conditions of access and use can be found at http://hrmars.com/index.php/pages/detail/publication-ethics 


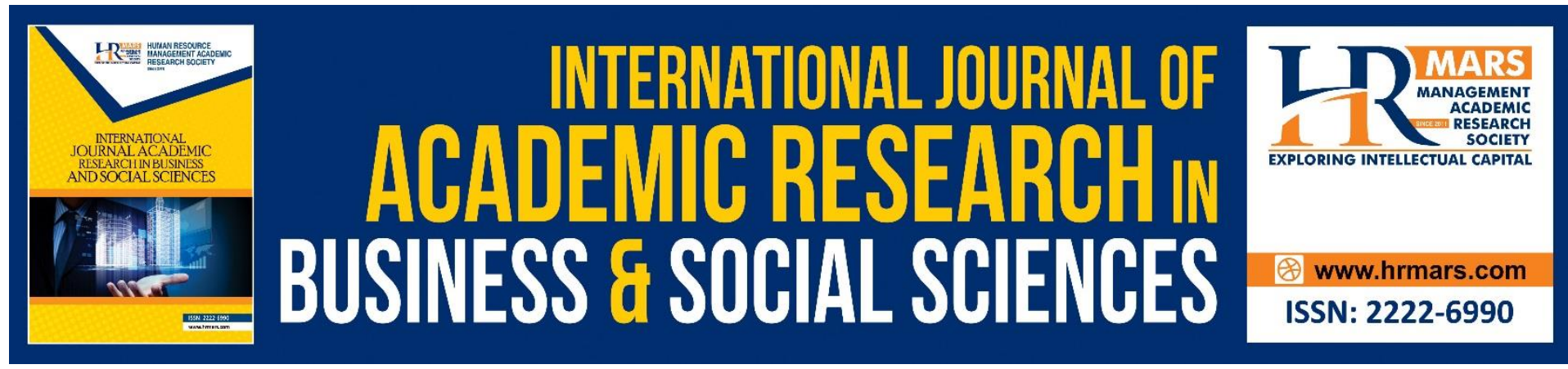

\title{
The Relationship Between Marketing Mix and Customer Loyalty among Malaysian Smartphone Users
}

Nur Najjah Abd Rahim ${ }^{1}$, Mohd Zamri Abu Bakar², Ariff Azly Muhamed $^{3}$, Mazuin Mat Halif ${ }^{4}$, Mohd Faizul Hassan ${ }^{5}$

${ }^{1}$ Faculty of Business Management, Universiti Teknologi MARA Malaysia, ${ }^{2}$ Faculty of Business

Management, Universiti Teknologi MARA Malaysia, ${ }^{3}$ Faculty of Business Management, Universiti Teknologi MARA Malaysia, ${ }^{4}$ Faculty of Business Management, Universiti Teknologi MARA Malaysia, ${ }^{5}$ Faculty of Business Management, Universiti Teknologi MARA, Malaysia

\begin{abstract}
This paper seeks to discuss the role of marketing mix 4Ps model (product, price, place and promotion) on the relationship with customer loyalty among Malaysia smartphone users. Smartphone have become almost inseparable in today's digital world. This growth is being stimulated by a variety of factors including social distancing, affordable price, trending lifestyle, more usage of smartphone capabilities, aggressive marketing campaign and robust business strategies by smartphone brands. This paper recommended that all of the marketing mix variables namely; product, price, place, and promotion, have positive significant with customer loyalty specifically among smartphones users in Malaysia. Thus, companies will be required to embrace the variables that, in turn, will enable them to develop effective and efficient plans that incorporate the criteria described in order to increase customer loyalty.

Keywords: Price Product, Place, Promotion.
\end{abstract}

\section{Introduction}

In today competitive business environment, a company's success and sustainability is dependent on its ability to win over its customers' hearts and attentions. The fact that one is working in the industry itself, with so many competitors and economic uncertainty, means that one must overcome numerous challenges. In order for a company to remain competitive in the industry, they must surpass in achieving high levels of customer satisfaction and loyalty in the delivery of its products nor services, which is especially critical elements within the context of mobile telecommunication industry (Danish et al., 2015). Critical factors such economic stability, pricing and technological influences, as well as the advancement of marketing in the worldwide telecommunications industry, the development of communication services is being pushed forward. Consequently, there is intense competition in terms of technologies, product, cost and the process of meeting customer needs and want, mobile consumer devices specifically smartphone industry is experiencing numerous hitches (Chuah et al., 2015). Within the context of Malaysia, the popular smartphone brands namely; 
Apple, Huawei, OPPO, Samsung, Realme, Vivo, and Xiaomi which are collectively referred to as the country's synonyms smartphone brands which constantly pursue aggressive planning, promotion and robust marketing strategies to retained loyalty of their customers.

According to statistics, there are approximately 30.41 million smartphone users in Malaysia (Suprami, 2020). In fact, according to the report, the younger generation under the age of 30 years old accounts for the majority of smartphone users in Malaysia and has proven to be a lucrative business. In order to remained relevant and winning market shares, marketing mix is a common tool used by a businesses to attract customer and manipulate them into making a purchase choice, hence increasing the revenue of the companies (Kumar, 2018). It is an important component of an effective marketing strategy if a company wishes to market its products through four important elements: product, price, place, and promotion or better known as 4P's. Similarly, Bahadir et al (2015) review that 4P's elements are the controllable tools that will have a direct impact on the customer's overall satisfaction with the product. This statement supported by Othman etal (2021) that suggested when a company implements a marketing mix in their business, it will boost the organisation with customer retention, increasing its sales and earnings over time. In facts, several researchers have used the 4Ps as a source of inspiration in their investigations into the impact of customer satisfaction, brand loyalty, sales and firm financial values (Datta et al., 2017; Hanssens et al., 2001; Srinivasan \& Hanssens, 2009). It is the purpose of this study to respond to this question by evaluating the impact of the marketing mix on customer loyalty among smartphone users in Malaysia.

\section{Literature Review \\ Customer Loyalty}

Customer loyalty can be defined as a state that it is "a firmly held commitment by the customer, to re-buy or re-patronize a favoured product or service in the future, resulting in repetitive same-brand or same brand-set purchase (Zeithaml, Berry, \& Parasuraman, 1996). It understood as considerable behaviour and expressed in the highest form of customer emotional adherence to the brand and business by recommending a product or service to others or by spreading positive word of mouth. Further, a customer's repurchase behaviour is considered to be the most fundamental requirement for loyalty. Every firm must assess the extent to which its marketing mix plan will contribute to customer pleasure as well as customer loyalty in order to be successful (Kumar, 2018). Customer perceptions of value are influenced by the packaging, services, and benefits of products or services. As a result, customers are more likely to express their complete loyalty to a brand (Gao et al., 2021). Consequently, the smartphone brands consistently plan aggressive and innovative planning for its marketing tools in order to ensure they acquire loyalty from its existing nor future potential customers.

\section{Product}

According to the definition, product is anything that can be supplied to a market for the purposes of attention, purchase, usage, or consumption in order to satisfy a need or need (Kotler \& Amstrong, 2011). It also broadly defined as physical objects, services, events, persons, places, organizations, ideas, or mixtures of these entities. The product offered by the smartphone brands is used to determine the bundles that are available in this study. It has a significant impact on a customer's decision to acquire a product or services. As a result, when developing a product or service, the package of benefits in the service provided must be 
considered from the perspective of the consumer (Kushwaha \& Agrawal, 2015). In any marketing campaign, the product is an essential component (Chua et al., 2015). The nature of the product has been identified as the most important factor in the smartphone brands according to the findings of the previous study by Shafei \& Tabaa, (2016). The nature of the smartphone has an important role in determining the brand preferences of brand providers. Thus, the following hypothesis is proposed:

H1: Products significantly influence Customer Loyalty among Malaysia Smartphone Users

\section{Price}

It is conceivable that price will be deemed an attribute that must be sacrificed in order to receive specific types of items or services (Kushwaha \& Agrawal, 2015). The service pricing structure must be more accommodating to the customer's financial situation in order for him or her to be able to afford it and be convinced by the activity. Pricing decisions play an important role in marketing strategy because they determine where the price should be put in relation to other variables such as the smartphone life cycle, sales targets, and market share. In fact, pricing is a good indicator of product quality, and high-value brands are referred to as "wonderful brands" (Kim, Lee, Kwon, Pak, \& Back (2022). Furthermore, because the nature of a smartphone is standard and can be easily proved, a higher price may hinder consumer loyalty because it may not be an indication of superior quality and may only draw attention to the fact that there is more money that needs to be spent. Thus, the following hypothesis is proposed:

$\mathrm{H} 2$ : Price significantly influence towards Customer Loyalty among Malaysia Smartphone Users

\section{Place}

The mechanism by which goods and services are moved from the provider or manufacturer to the consumer is referred to as the place (Goi, 2009). According to Kotler (1976), place is comprised of distribution channels, geographic location, and coverage. The term "place" to the natural process followed by an organization in order to distribute goods or services to a client. While the phrase "place" may seem to be the most basic term in the 4Ps marketing mix, it plays a significant part in the many marketing elements. While the term "place" may seem to be the most basic term in the 4Ps marketing mix, it plays an important role in the various marketing elements. It is also linked to a successful distribution process, which enables the organization to meet the availability goal of delivering the product in the right place and at the right time. Thus, it is critical that the smartphone specifically new launching smartphone is available in the markets either in physical store or online platforms. This includes a network of individuals and organizations such as distributors, wholesalers, and retailers who work together to shape the organization's distribution network (the channel of distribution). Thus, the following hypothesis is proposed:

H3: Place significantly influence towards Customer Loyalty among Malaysia Smartphone Users

\section{Promotion}

The term "promotion" refers to the communication strategy employed by marketers to make customers aware of their product offerings (Drummond \& Ensor, 2006). It is considered as an effort to encourage customers to tell others about a company's products or services and to persuade product markets. Every smartphone brands relies on promotion to pursue and encourage clients in the market to purchase their smartphones and services. Promotion is a 
vital component of any marketing strategy that that can be directed through personal selling points or media advertising (Kotler \& Armstrong, 2011). Lin and Bennett (2014) in their study discovered that customers who were satisfied with their experiences in offline stores were more likely to repurchase and recommend the store, as well as being more resistant to competitive promotions and advertising. Marketing methods such as advertising and endorsements are used to increase brand awareness and reputation, as well as to persuade people to purchase a smartphone brand. Companies that have a higher commitment to their target market typically employ a variety of marketing techniques to advertise their smartphone and services to increase higher purchasing volume. Advertising, personal selling, publicity, sales promotion, and word-of-mouth are all examples of typical effective promotional activities among smartphone brand. Thus, the following hypothesis is proposed: $\mathrm{H} 4$ : Promotion significantly influence towards Customer Loyalty among Malaysia Smartphone Users

Figure 1 shows conceptual framework for this study :

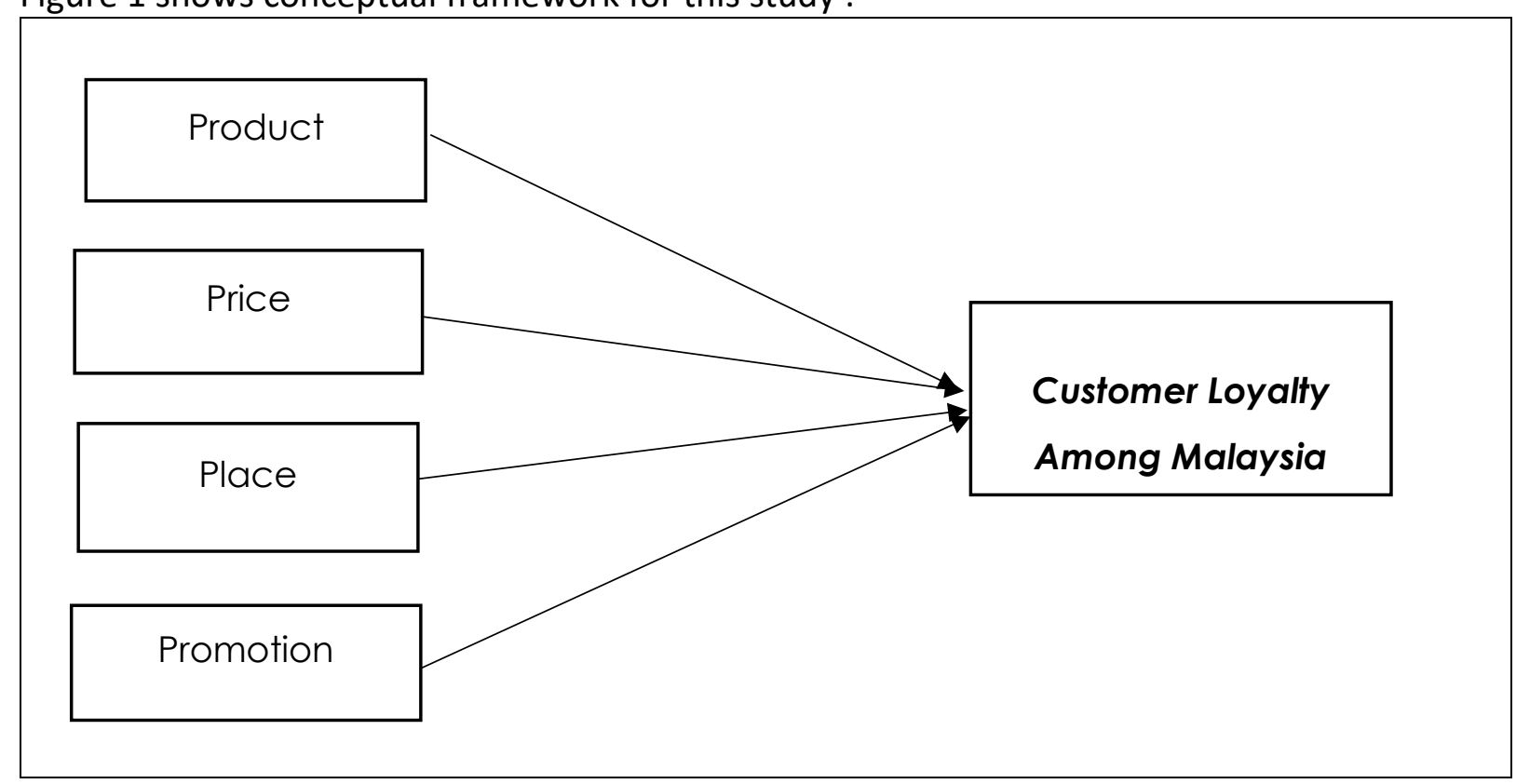

Figure 1: Conceptual model of study

\section{Conclusion}

Specifically, the objectives of this study is to identify the components of the traditional marketing mix that influence customer loyalty in order to determine the appropriate marketing mix elements on smartphone, specifically within the context of Malaysian users. Based on the discussion above regarding the impact of marketing mix elements (product, price, place, and promotion) on customer loyalty among Malaysia smartphone users, this study concludes that the marketing mix elements refers to product, price, place and promotion have a significant roles to play in achieving a competitive advantage on the part of customer loyalty. This shows that, in a very sensitive market climate, smartphone manufacturers should pay particular attention to this element. This study demonstrates that marketing mix factors play a key influence in establishing and increasing client loyalty among smartphone users in Malaysia.

Customers are now seeking for a good deal from a smartphone brands before purchasing their preferred brand. The findings of the research illustrate the fundamental 
significance of the elements of the marketing mix in the smartphone sector as a whole. Further, the findings provide smartphone companies with a greater knowledge of the importance of identifying the critical aspects that drive client loyalty among their existing customer. Consequently, companies will be required to embrace the variables that, in turn, will enable them to develop effective and efficient plans that incorporate the criteria described in order to increase customer loyalty and brand awareness. In addition, companies will be able to tailor their smartphone offers to meet the needs of their customers as their tastes evolve. The development of a successful marketing plan is possible because it can contribute to customer decision-making and the acquisition of a competitive advantage. When it comes to understanding how marketing mix strategies are essential in maintaining a long-term relationship with customers, this study will be of interest to mobile companies in Malaysia and around the world.

\section{References}

Bahadir, S. C., Bharadwaj, S. G., \& Srivastava, R. K. (2015). Marketing mix and brand sales in global markets: Examining the contingent role of country-market characteristics. Journal of International Business Studies, 46(5), 596-619.

Chuah, H. W., Marimuthu, M., \& Ramayah, T. (2015). Wireless telecommunications industry in Malaysia: Trends, challenges, and opportunities. In consumption in Malaysia: Meeting of new changes. Universiti Sains Malaysia Publisher, Penang.

Datta, H., Ailawadi, K. L., \& van Heerde, H. J. (2017). How well does consumer-based brand equity align with sales-based brand equity and marketing mix response? Journal of Marketing, 81(3), 1-20.

Danish, R. Q., Ahmad, F., Ateeq, A., Ali, H. Y., \& Humayon, A. A. (2015). Factors affecting customer retention in telecommunication sector of Pakistan. American Journal of Marketing Research, 1(2), 28-36.

Drummond, G., \& Ensor, J. (2006). Introduction to Marketing Concepts. Butterworth Heinemann, Burlington: Oxford.

Goi, C. L. (2009). A review of marketing mix: 4Ps or more? International Journal of Marketing Studies, 1(1), 2-15.

Gao, W., Fan, H., Li, W., Wang, H. (2021). Crafting the customer experience in omnichannel contexts: the role of channel integration. Journal of Business Research, 126, 12-22.

Hanssens, D. M., Parsons, L. J., \& Schultz, R. L. (2001). Market response models: Econometric and time series analysis ( $2^{\text {nd }}$ ed.). Kluwer Academic Publishers.

Kim, J., Lee, M., Kwon, W., Pak, H., \& Back, K. (2022). Why am I satisfied? See my reviews Price and location matter in the restaurant industry. International Journal of Hospitality Management, 101, ISSN 0278-4319, doi.org/ 10.1016/j. ijhm.2021. 103111.

Kotler, P. (1976). Applying marketing theory to college admissions. In: College Entrance Examination Board (Ed.), A Role for Marketing in College Admissions. College Entrance Examination Board, New York, pp. 54-72.

Kotler, P., \& Keller, K. L. (2009). Marketing management (13 ${ }^{\text {th }}$ ed.) Upper Saddle River, NJ: Prentice-Hall.

Kotler, P., \&Armstrong, G. (2011). Principles of Marketing (14 ${ }^{\text {th }}$ ed.). Edinburgh Gate Harlow Essex, England. Pearson Education.

Kumar, V. (2018). Transformative marketing: The next 20 years. Journal of Marketing, 82(4), $1-12$. 
Kushwaha, G., and Agrawal, S. (2015). An Indian customer surrounding 7P 's of service marketing. Journal of Retailing and Consumer Services, 22, 85-95.

Othman, B., Weijun, H., Huang, Z., Xi, J., \& Ramsey, T. (2021). The effects on service value and customer retention by integrating after sale service into the traditional marketing mix model of clothing store brands in China. Environmental Technology \& Innovation 23. 10178.doi.org/10.1016/j.eti.2021.101784

Shafei, I., \& Tabaa, H. (2016). Factors affecting customer loyalty for mobile telecommunication industry. EuroMed Journal of Business, 11(3), 347-361.

Srinivasan, S., \& Hanssens, D. M. (2009). Marketing and firm value: Metrics, methods, findings and future directions. Journal of Marketing Research, 46(3), 293-312.

Suprami, S. (2020). Being smart about smartphones. The Sun Daily. https://www.thesundaily.my/local/being-smart-about-smartphones-DH4889885

Zeithaml, V. A., Berry, L. L., \& Parasuraman, A. (1995). The nature and determinants of customer expectations of service. Journal of the Academy of Marketing Science, 21(1), $1-12$. 